\title{
Hunting Pressure on Orang-utans in Sarawak
}

\section{Lord Medway}

In Sarawak a comparatively new development is that orang-utans are being hunted for food, often with great cruelty. The Government is aware of the threat to the population, and special reserves are being considered. Lord Medway points out that only a change in local sentiment will save the orang-utans even in sanctuaries - they already have full legal protection - and suggests an appeal must be made to people to return to traditional ways.

The international ban on zoos acquiring wild-caught orang-utans may have been reasonably successful outside their source region (compare ${ }^{1,5}$ ), but the surviving wild populations continue to be subject to unremitting pressure. (The situation in Sumatra has recently been summarised in Ory $x^{2}$.) In Sabah, in 1964, at Poring - near the eastern boundary of the Kinabalu National Park - I met men who readily admitted that they had shot and eaten the Maias (orang-utan), and now, in Sarawak, orang-utans are being hunted and killed for food. Charred remains - skin, skulls and limb bones - obtained in July 1975 from camp sites and field huts adjoining the forested area of the upper Sebuyau (about $111^{\circ} \mathrm{E}, 1^{\circ} 20^{\prime} \mathrm{N}$ ) provide indisputable evidence. One skull (that of a young female) had been opened along the sagittal plane, obviously in order to extract the brain, and there can be no doubt that these animals had been eaten.

In Sarawak in historic times orang-utans have traditionally not been hunted for food. In 1960, despite 'several reports' that orang-utans had been shot to obtain the meat 'which is relished by some people', Bruen and Haile ${ }^{3}$ concluded that 'there is no doubt that the majority of the Dayaks favour the protection of the Maias. The Maias is generally harmless, and has always been considered to be so. ... It is contrary to the custom of some, at least, of the Iban, and considered mali (taboo), to kill Maias unless they are forced to do so in self-defence'. At about this time, too, Barbara Harrisson found wild orang-utans in the Sebuyau district ${ }^{4}$ but noted no instances of deliberate hunting, further evidence of a recent change in customary attitudes. To some extent this may be related to the reduction in numbers of conventional game. Sarawak country people are keen hunters, and a high proportion own guns. Even in 1960, 7086 persons in the villages adjacent to the Sebuyau Protected Forest owned between them 476 shotguns $^{3}$ - both figures are certainly higher today. As a general control measure, at present the number of cartridges that can be bought by any licensed gun-owner is limited. This restriction, however, has the unfortunate effect of encouraging the hunting of large animals, such as orang-utans, rather than smaller alternatives such as squirrels, because they provide a relatively greater yield of meat.

The use of shotguns against orang-utans, which can seldom be killed outright, inevitably involves great cruelty. The hunter can only hope to wound his quarry and bring it to the ground to be killed by a bush-knife. A second skull from Sebuyau tells a grisly tale. Clearly seen is a deep diagonal slash 


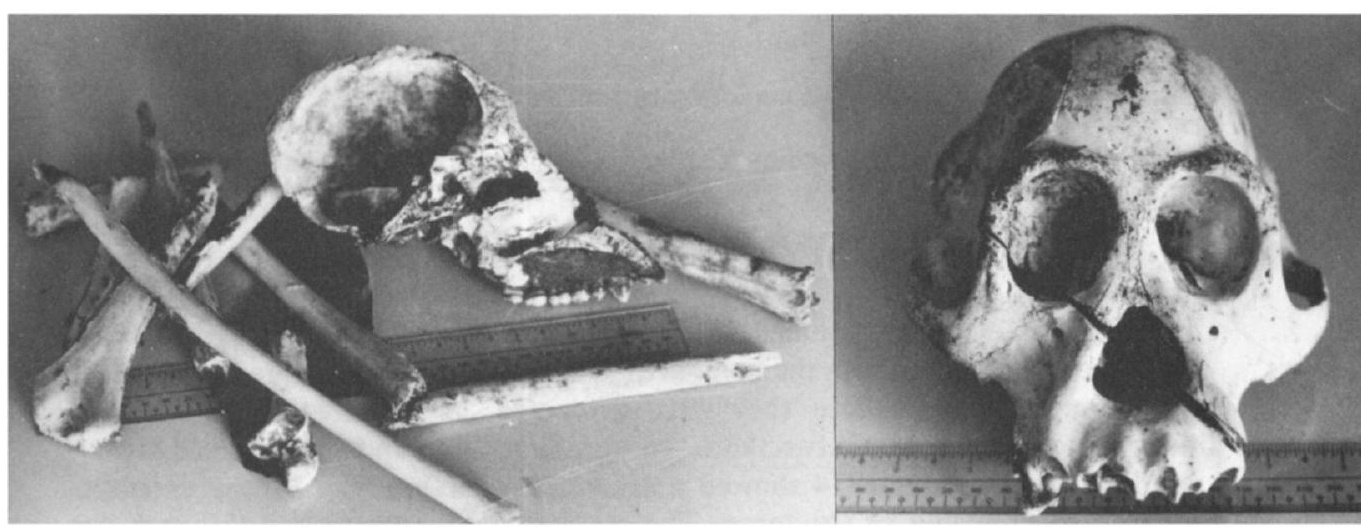

Left: Limb bones, a piece of skin and the halved skull of a young female orang-utan, all charred; the long bones have also been gnawed by dogs.

Right: The skull of an old female shows a single knife cut which must have destroyed the right eye, severed the nose and smashed the left upper jaw.

slanting across the face from the right orbit, through the nasal region and the left upper jaw. This blow touched no vital organ, and cannot have been the final cause of death, but it was delivered with such force that the upper jaw on the left side was fractured beyond the edge of the knife blade and largely detached from the cranium. The suffering of this orang-utan (an aged female, possibly vulnerable because she was pregnant or carrying a young infant) as she faced her attackers is horrible to imagine.

The Sarawak Government are not unaware of the threat to orang-utans, which have been totally protected by law for three decades. An Office of National Parks and Wildlife has been formed, and special reserves are envisaged. Yet, patently, in the rural districts the law is not respected, and present Wildlife personnel includes no trained field enforcement officers. To establish effective orang-utan reserves will necessitate the permanent dedication of large tracts of unspoiled lowland forest in the range of existing populations. Natural densities quoted by Borner ${ }^{2}$ imply requirements of about 1 sq $\mathrm{km}$ per animal, but it may be difficult to reserve such large areas $-100 \mathrm{sq} \mathrm{km}$ $(24,710$ acres $)$ for a mere 100 orang-utans - in the face of demands for rural development land.

Even if adequate sanctuaries can be set aside, the orang-utans there will only survive if their protection is supported by local sentiment. The opportunity seems to exist for a call to the Iban villagers, preferably through community leaders, to return to traditional attitudes towards orang-utan. A simultaneous campaign to encourage a greater reliance on domestic animals for meat would also be valuable. The cruelty issue is an influential aspect in urban educated societies, but perhaps less so in rural communities. In any event, it is now clear that the future of the orang-utans within the State is secure only if all Sarawakans unite in their resolve to protect the surviving remnants.

\section{References}

1. ANON. 1976. What is going on. Oryx 13: 252.

2. BORNER, M. 1976. Sumatra's Orang-utans. Oryx 13: 290-293.

3. BRUEN, D.L. and HAILE, N.S. 1960. Report of the Maias Protection Commission. Government Printer, Sarawak.

4. HARRISSON, B. 1962. Orang-utan. Collins, London.

5. PERRY, J. 1976. Orang-utans in captivity. Oryx 13: 262-264. 